\title{
Effect of Thrombin on the Fibrinolytic Activity of Cultured Bovine Endothelial Cells
}

\author{
David J. Loskutoff, Department of Molecular Immunology, \\ Research Institute of Scripps Clinic, La Jolla, California 92037
}

\begin{abstract}
A B S T RACT The vascular endothelium is a rich source of plasminogen activator (PA) and thus of blood vessel-associated fibrinolytic activity. Cultured bovine aortic endothelial cells were employed to determine if components of the coagulation system interact with the endothelium to modify expression of this activity. The addition of thrombin to these cultures led to a rapid decline in intracellular PA activity, with as little as $3 \mathrm{ng} / \mathrm{ml}$, or $0.1 \mathrm{nM}$ thrombin causing a $50 \%$ decrease within $30 \mathrm{~min}$. Thrombin inactivated with diisopropylfluorophosphate or hirudin did not elicit the response. Although control cultures secreted high levels of PA, no PA activity could be detected in the media surrounding the thrombin-treated cells. This loss of activity did not appear to result from direct inactivation of PA by thrombin. These observations indicate that the fibrinolytic potential of cultured endothelial cells is rapidly suppressed by trace amounts of thrombin. The generation of thrombin at sites of vascular injury may have a similar effect on the endothelium.
\end{abstract}

\section{INTRODUCTION}

The production of plasminogen activator $(\mathrm{PA})^{1}$ by the endothelium (1) emphasizes the potential role of endothelial cell(s) (EC[s]) in maintaining vessel patency and initiating thrombolysis. At the same time, however, the presence of PA in the area of vascular injury would appear to compromise the hemostatic function of the damaged endothelium by converting circulating plasminogen into plasmin (2) and thus initiating premature lysis of the fibrin-platelet thrombus. We have been

Portions of this work were presented at the meetings of the American Society of Hematology, New Orleans, La., and published in 1978. Blood. 52(Suppl. 1): 343. This is publication number 1759 of Scripps Clinic and Research Foundation.

Received for publication 5 April 1979 and in revised form 2 May 1979.

${ }^{1}$ Abbreviations used in this paper: $\mathrm{CM}$, conditioned media; DFP, diisopropylfluorophosphate; EC(s), endothelial cell(s); MEM, modified Eagle's medium; PA, plasminogen activator; PBS, 0.14 M NaCl, 0.01 M sodium phosphate, pH 7.3. employing cultured ECs to study factors that influence expression of PA by the endothelium $(3,4)$. Here we show that the addition of physiological concentrations of thrombin to these cultures rapidly reduces intracellular PA activity, and at the same time severely depresses its rate of secretion. The generation of thrombin at sites of vascular injury may have a similar effect on the endothelium, thus protecting the growing thrombus against premature, EC-mediated dissolution.

\section{METHODS}

Cell culture. ECs were isolated from the aortas of freshly slaughtered adult cows by gentle collagenase treatment (5). Cells were cultured in 35- $\mathrm{mm}$ tissue culture dishes in $1 \mathrm{ml}$ of modified Eagle's medium (MEM) supplemented with $10 \%$ fetal calf serum (Reheis Co., Inc., Phoenix, Ariz.) as described $(3,4)$. Cultures were seeded at 200,000 cells/dish, grew with a generation time of $24-28 \mathrm{~h}$, and reached a density of $0.8-1.2$ $\times 10^{6}$ cells/dish at confluency. These monolayers were wellcontact inhibited and could be maintained for $2-4 \mathrm{wk}$ without refeeding and without change in culture morphology. The cells used in these experiments had been subcultured 15-20 times and were employed 1-7 d after visual confluency was reached. Similar results were obtained in preliminary experiments with cells passaged only three times.

Preparation of cell extracts and conditioned media. Monolayers were washed three times with cold phosphate-buffered saline (PBS) and either extracted with 0.5\% Triton X-100 (Rohm and Haas Co., Philadelphia, Pa.) (3), or incubated in serum-free MEM at $37^{\circ} \mathrm{C}$ for various times to prepare conditioned media (CM) containing PA. The extracts and CM were then assayed for fibrinolytic activity. Hirudin (Sigma Chemical Co., St. Louis, Mo.) was added to CM collected from thrombin-treated cultures. It did not affect fibrinolysis assays.

Fibrinolytic activity. ${ }^{125}$ I-Fibrin-coated multiwell culture dishes were prepared as described (3) and employed to measure the fibrinolytic activity of cell extracts and $\mathrm{CM}$. Each well contained $20 \mu \mathrm{g}$ fibrinogen and $100,000 \mathrm{cpm}$. The rate of fibrinolysis was determined by monitoring the release of radioactivity from the surface of the dish into the assay buffer at various times. The standard cell-free assay contained in $1 \mathrm{ml}$ : $4 \mu \mathrm{g}$ human plasminogen, $0.1 \%$ gelatin, $0.5 \%$ Triton X-100, and $0.1 \mathrm{M}$ Tris- $\mathrm{HCl}, \mathrm{pH} 8.1$, and was supplemented with cell extract or CM as a source of PA. Background fibrinolysis observed in the absence of a PA source was subtracted from each sample. Fibrinolytic activity was not observed in the 
absence of plasminogen. The results are the average of duplicate determinations and represent $<15 \%$ variation.

Thrombin treatment. Monolayers were incubated at $37^{\circ} \mathrm{C}$ for various times in serum-free MEM containing human $\alpha$-thrombin (kindly provided by Dr. J. W. Fenton, Jr.: 2,545 $\mathrm{NIH} \mathrm{U/mg),} \mathrm{and} \mathrm{cell} \mathrm{extracts} \mathrm{and} \mathrm{CM} \mathrm{were} \mathrm{prepared.} \mathrm{Inactive}$ thrombin was prepared by incubating thrombin $(100 \mathrm{U} / \mathrm{ml}$ in PBS containing $0.1 \%$ gelatin) with $500 \mathrm{U} / \mathrm{ml}$ of hirudin or $10 \mathrm{mM}$ diisopropylfluorophosphate (DFP) for $2 \mathrm{~h}$ at $37^{\circ} \mathrm{C}$. The DFP-treated sample was dialyzed overnight against $\mathrm{PBS}$ at $4^{\circ} \mathrm{C}$.

Miscellaneous. Human plasminogen was prepared by lysine affinity chromatography (6), protein was determined by the method of Bradford (7), and radioactivity was measured in a Packard gamma spectrometer (Packard Instrument Co., Inc., Downers Grove, Ill.). All chemicals and reagents were of analytical grade.

\section{RESULTS}

Effect of thrombin on intracellular PA activity. Thrombin binds to ECs with high affinity (8), causing alterations in prostacyclin production (9). EC monolayers were incubated with increasing concentrations of thrombin to determine whether production of other endothelial products is also influenced by this enzyme. No change in the morphology of these cells was observed, even after $24 \mathrm{~h}$ in the presence of $10 \mathrm{U} / \mathrm{ml}$ of thrombin. However, thrombin dramatically reduced intracellular PA activity (Fig. 1), with as little as 2.5 $\mathrm{mU} / \mathrm{ml}$ causing a significant decrease within $30 \mathrm{~min}$. The maximum decrease was consistently observed at $2-4 \mathrm{U} / \mathrm{ml}$, and resulted in a loss of $75-95 \%$ of the activity. The half-maximal response was elicited with 7-10 $\mathrm{mU} / \mathrm{ml}$, or $\cong 0.1 \mathrm{nM}$ thrombin. Thrombin pre-

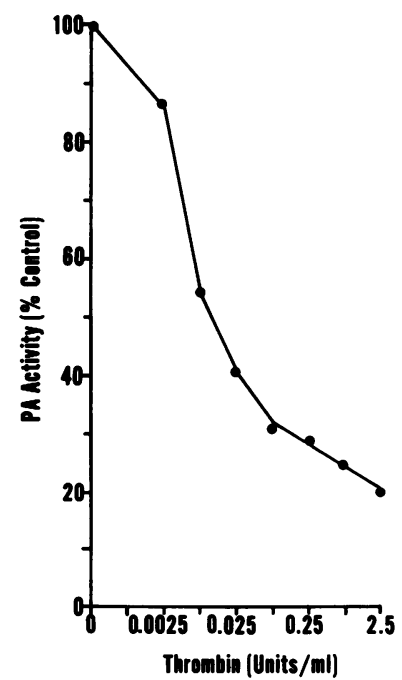

Figure 1 Effect of thrombin on intracellular PA activity. EC monolayers were incubated for $30 \mathrm{~min}$ in the presence of increasing concentrations of thrombin, extracted, and tested for PA activity. The PA activity in $5 \mu \mathrm{g}$ of each extract was normalized to that in the untreated control cultures which hydrolyzed $20 \%$ of the fibrin in the 2 -h assay.
TABLE I

Effect of Inactive Thrombin on Intracellular PA Activity

\begin{tabular}{lrr}
\hline \multicolumn{1}{c}{ Treatment* } & $\begin{array}{c}\text { Counts per } \\
\text { minute } \\
\text { released }\end{array}$ & $\begin{array}{c}\text { Percentage } \\
\text { of untreated } \\
\text { control }\end{array}$ \\
\hline Untreated control & 29,340 & 100 \\
Thrombin $(1 \mathrm{U} / \mathrm{ml})$ & 6,885 & 23 \\
DFP-thrombin $(10 \mathrm{U} / \mathrm{ml})$ & 24,125 & 82 \\
Hirudin-thrombin $(10 \mathrm{U} / \mathrm{ml})$ & 29,405 & 100 \\
\hline
\end{tabular}

* Monolayers were exposed to various thrombins for $30 \mathrm{~min}$ under culture conditions, washed, and extracted. The PA activity of each extract was compared to that of the untreated control.

$\ddagger$ Counts per minute released by $5 \mu \mathrm{g}$ extract in the standard assay in $2 \mathrm{~h}$.

treated with hirudin or DFP (Table I) did not cause the decrease, even when tested at $10 \mathrm{U} / \mathrm{ml}$.

Effect of thrombin on secretion of PA. Thrombin stimulates secretion by platelets (10) and fibroblasts (11). CM was prepared from thrombin-treated and untreated monolayers to test the possibility that the decrease in intracellular PA was also due to secretion. Washed monolayers were exposed to thrombin (1 $\mathrm{U} / \mathrm{ml}$ ), and at various times thereafter an aliquot of the media was removed and tested for PA activity (Fig. 2). PA activity was high in CM removed from untreated cultures. It was detected within the first $30 \mathrm{~min}$ and continued to accumulate for the next $3.5 \mathrm{~h}$. In contrast,

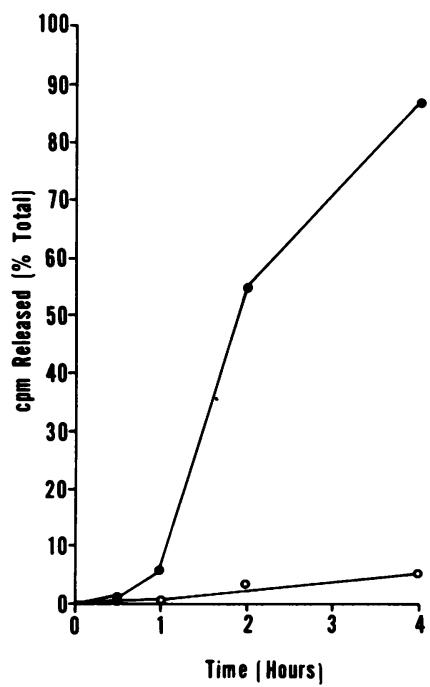

FIGURE 2 Accumulation of PA activity in media from thrombin-treated and untreated ECs. Thrombin $(1 \mathrm{U} / \mathrm{ml})$ was added to EC monolayers. At various times an aliquot $(25 \mu \mathrm{l})$ of the media was removed and tested for PA activity in assay buffer containing hirudin $(1 \mathrm{U} / \mathrm{ml})$. Untreated $(0)$ and thrombin treated $(\mathrm{O})$. 
only minimal PA activity was detected in the thrombintreated cultures. CM prepared for $4 \mathrm{~h}$ from treated cultures had less PA activity than CM recovered from untreated cultures after only $1 \mathrm{~h}$.

Effect of thrombin on PA itself. The low PA activity of CM from thrombin-treated cultures did not result from direct inactivation of PA by the thrombin. Thus, when thrombin was added to the media covering cultured cells, intracellular and secreted PA decreased by 80 and $92 \%$, respectively, within $30 \mathrm{~min}$ (Table II). However, when it was added directly to CM previously removed from cells, the rate of loss was considerably slower. Under these conditions, the activity declined by only $16 \%$ in $30 \mathrm{~min}$. Approximately $60 \%$ of the control activity still remained after $90 \mathrm{~min}$ of treatment. Thrombin incubated with $\mathrm{CM}$ for $90 \mathrm{~min}$ still retained its procoagulant activity as measured in a fibrinogen clotting assay.

\section{DISCUSSION}

Thrombin is a highly specific serine protease whose primary biological activity appears to be related to its effect on platelets (10) and its critical role in blood coagulation (12). It is also apparent, however, that thrombin may influence the behavior of a variety of cells. Thus, it is mitogenic for some cells $(13,14)$, it stimulates the production and release of fibronectin from the surface of fibroblasts (11), and it enhances the release of prostacyclin from ECs (9). The results presented in this communication implicate thrombin in the control of vascular fibrinolysis.

The addition of physiological concentrations of thrombin to confluent monolayers of bovine ECs caused a rapid and extensive loss of intracellular PA activity (Fig. 1). The half-maximal response was observed at

TABLE II

Changes in PA Activity after Thrombin Treatment

\begin{tabular}{lrcr}
\hline & \multicolumn{3}{c}{ PA activity at various times } \\
\cline { 2 - 4 } Sample & $30 \mathrm{~min}$ & $60 \mathrm{~min}$ & $90 \mathrm{~min}$ \\
\hline & \multicolumn{4}{c}{$\%$ untreated control } \\
Cultured cells* & \multicolumn{3}{c}{} \\
Intracellular & 20 & 17 & 14 \\
Extracellular & 8 & 3 & 6 \\
Media alone & 84 & 84 & 60 \\
\hline
\end{tabular}

* Monolayers were exposed to thrombin $(1 \mathrm{U} / \mathrm{ml})$, and at the indicated times cell extracts (intracellular) and CM (extracellular) were tested for PA activity. The results are compared to those obtained from the appropriate untreated controls.

\$ Serum-free CM was prepared overnight, removed from cells, and treated with thrombin for the indicated times. The results are expressed as the percentage of untreated, incubated controls. $\cong 0.1 \mathrm{nM}$ thrombin, in agreement with the dissociation constant for the thrombin-EC receptor (8). The decrease was complete within $30 \mathrm{~min}$ (Table II), and in preliminary kinetic experiments, thrombin $(1 \mathrm{U} / \mathrm{ml})$ reduced intracellular PA activity by $65 \%$ within $1 \mathrm{~min}$ at $37^{\circ} \mathrm{C}(15)$.

The mechanism by which thrombin caused the decrease in intracellular PA activity is unclear. DFP-inactivated thrombin still binds to ECs (8), but active thrombin is apparently required both to suppress intracellular PA (Table I), and to stimulate prostacyclin release (9). The mitogenic activity of thrombin can be accounted for entirely by its action on the cell surface (16), suggesting that its effect on PA may be initiated by similar surface changes. In addition, it seems likely that intracellular calcium is important, because the presence of calcium ionophore also decreases intracellular PA (15) and stimulates prostacyclin release (9). Thrombin itself causes a rapid influx of calcium ions into ECs (17). How changes in the concentration of this important regulatory ion lead to loss of intracellular $\mathrm{PA}$ is unclear. Elevated rates of secretion appear to be ruled out since PA is secreted at a much lower rate in the presence of thrombin (Fig. 2). The possibility that thrombin itself directly inactivated PA was considered. Although the addition of thrombin to $\mathrm{CM}$ appeared to inactivate PA, it did so at a rate considerably slower than the observed loss (Table II). The possibilities that thrombin activates a cellular inhibitor of fibrinolysis $(3,4)$, initiates degradation of PA, or inhibits synthesis of PA are being investigated.

In conclusion, these results indicate that the generation of thrombin in the vasculature may promote hemostasis not only by aggregating platelets and promoting coagulation, but also by suppressing the thrombolytic potential of the endothelium.

\section{ACKNOWLEDGMENTS}

The author wishes to thank Dr. T. S. Edgington not only for encouraging and supporting this work, but also for providing the stimulating environment in which these studies were conducted. In addition the author acknowledges Ms. Karen Roegner for excellent technical assistance and Ms. Pat Moreland for typing the manuscript.

This work was supported by National Institutes of Health grant HL-22289.

\section{REFERENCES}

1. Astrup, T. 1978. Fibrinolysis: an overview. Prog. Chem. Fibrinolysis Thrombolysis. 3: 1-57.

2. Robbins, K. C., L. Summaria, and G. H. Barlow. 1975. Activation of plasminogen. In Proteases and Biological Control. E. Reich, D. Rifkin, and E. Shaw, editors. Cold Spring Harbor Press, Cold Spring Harbor, N. Y. 305-310.

3. Loskutoff, D. J., and T. S. Edgington. 1977. Synthesis of a fibrinolytic activator and inhibitor by endothelial cells. Proc. Natl. Acad. Sci. U. S. A. 74: 3903-3907.

4. Levin, E., and D. J. Loskutoff. 1979. Comparative studies 
of the fibrinolytic activity of cultured vascular cells. Thromb. Res. In press.

5. Booyse, F. M., B. J. Sedlak, and M. E. Rafelson, Jr. 1975. Culture of arterial endothelial cells. Characterization and growth of bovine aortic cells. Thromb. Diath. Haemorrh. 34: 825-839.

6. Deutsch, D. G., and E. T. Mertz. 1970. Plasminogen: purification from human plasma by affinity chromatography. Science (Wash. D. C.). 170: 1095-1096.

7. Bradford, M. M. 1976. A rapid and sensitive method for the quantitation of microgram quantities of protein utilizing the principle of protein-dye binding. Anal. Biochem. 72: 248-254.

8. Awbrey, B. J., J. C. Hoak, and W. G. Owen. 1979. Binding of human thrombin to cultured human endothelial cells. J. Biol. Chem. In press.

9. Weksler, B. B., C. W. Ley, and E. A. Jaffe. 1978. Stimulation of endothelial cell prostacyclin production by thrombin, trypsin, and the ionophore A23187. J. Clin. Invest. 62: 923-930.

10. Holmsen, H., and H. J. Day. 1970. The selectivity of the thrombin-induced platelet release reaction. Subcellular localization of released and retained constituents. J. Lab. Clin. Med. 75: 850-855.

11. Mosher, D. F., and A. Vaheri. 1978. Thrombin stimulates the production and release of a major surface-associated glycoprotein (fibronectin) in cultures of human fibroblasts. Exp. Cell Res. 112: 323-334.

12. Davie, E. W., K. Fujikawa, K. Kurachi, and W. Kisiel. 1979. The role of serine proteases in the blood coagulation cascade. Adv. Enzymol. Relat. Areas Mol. Biol. 48: 277-318.

13. Chen, L. B., and J. M. Buchanan. 1975. Mitogenic activity of blood components. I. Thrombin and prothrombin. Proc. Natl. Acad. Sci. U. S. A. 72: 131-135.

14. Gospodarowicz, D., K. D. Brown, C. R. Birdwell, and B. R. Zetter. 1978. Control of proliferation of human vascular endothelial cells. Characterization of the response of human umbilical vein endothelial cells to fibroblast growth factor, epidermal growth factor and thrombin. $J$. Cell Biol. 77: 774-788.

15. Loskutoff, D. J. 1978. Effect of thrombin on endothelial cell mediated fibrinolysis. Blood. 52(Suppl. 1): 343. (Abstr.)

16. Carney, D. H., and D. D. Cunningham. 1978. Cell surface action of thrombin is sufficient to initiate division of chick cells. Cell. 14: 811-823.

17. D'Amore, P., and D. Shepro. 1977. Stimulation of growth and calcium influx in cultured, bovine aortic endothelial cells by platelets and vasoactive substances.J. Cell. Physiol. 92: 177-184. 